\title{
Workforce Estimates for Environmental Restoration at Pinellas Plant
}

J. G. April

E. J. Stahlman

October 1993

Prepared for the U.S. Department of Energy under Contract DE-AC06-76RLO 1830

Pacific Northwest Laboratory

Operated for the U.S. Department of Energy by Battelle Memorial Institute 


\title{
DISCLAIMER
}

This report was prepared as an account of work sponsored by an agency of the United States Government. Neither the United States Government nor any agency thereof, nor Battelle Memorial Institute, nor any of their employees, makes any warranty, expressed or implied, or assumes any legal liability or responsibility for the accuracy, completeness, or usefulness of any information, apparatus, product, or process disclosed, or represents that its use would not infringe privately owned rights. Reference herein to any specific commercial product, process, or service by trade name, trademark, manufacturer, or otherwise does not necessarily constitute or Imply its endorsement, recommendation, or favoring by the United States Government or any agency thereof, or Battelle Memorial Institute. The views and opinions of authors expressed herein do not necessarily state or reflect those of the United States Government or any agency thereof.

\author{
PACIFIC NORTHWEST LABORATORY \\ operated by \\ BATTELLE MEMORIAL INSTITUTE \\ for the \\ UNITED STATES DEPARTMENT OF ENERGY \\ under Contract DE-ACO6-76RLO 1830
}

Printed in the United States of America

Available to DOE and DOE contractors from the

Office of Scientific and Technical Information, P.O. Box 62, Oak Ridge, IN 37831;

prices available from (615) 576-8401. FTS 626-8401.

Available to the public from the Nallonal Technical Information Service,

U.S. Department of Commerce, 5285 Port Royal Rd., Springfield, VA 22161. 


\title{
Workforce Estimates for Environimental Restoration at Pinellas Plant
}

\author{
J. G. April \\ E. J. Stahlman
}

October 1993

Prepared for the U.S. Department of Energy under Contract DOE-AC06-76RLO 1830

Pacific Northwest Laboratory Operated for the U.S. Department of Energy by Battelle Memorial Institute 


\section{Summary}

The purpose of this study was to assist the Pinellas Plant, Largo, Florida, in estimating workforce requirements for the anticipated environmental restoration (ER) mission. Pacific Northwest Laboratory (PNL) has prepared workforce estimates required for ER and the decontamination and decommissioning (D\&D) at Pinellas Plant. These estimates are presented in the report and were based on a comparison of several ER projects of similar magnitude, including Elmendorf Air Force Base in Alaska; Hanford in Richland, Washington; and the Radium Chemical D\&D project in Queens, New York. The characterization of the Pinellas Plant was based on the RCRA [Resource Conservation and Recovery Act] Facility Investigation Report: Pinellas Plant. 


\section{Contents}

Summary $\ldots \ldots \ldots \ldots \ldots \ldots \ldots \ldots \ldots \ldots \ldots \ldots \ldots \ldots \ldots \ldots \ldots \ldots$ iii

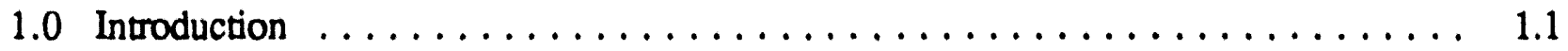

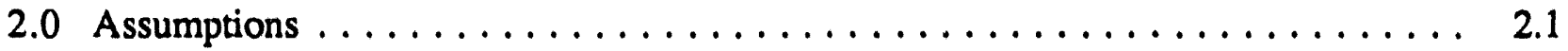

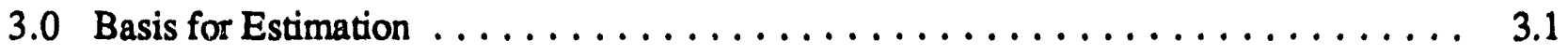

4.0 Workforce/Classification Evaluation $\ldots \ldots \ldots \ldots \ldots \ldots \ldots \ldots \ldots \ldots .1$

5.0 Schedules for RCRA Environmental Restoration Process from CMS to Site Closeout $\ldots \ldots \ldots \ldots \ldots \ldots \ldots \ldots \ldots \ldots \ldots \ldots . \ldots \ldots$

6.0 References $\ldots \ldots \ldots \ldots \ldots \ldots \ldots \ldots \ldots \ldots \ldots \ldots \ldots \ldots \ldots .6 .1$

\section{Figures}

4.1 Corrective Action Process $\ldots \ldots \ldots \ldots \ldots \ldots \ldots \ldots \ldots \ldots \ldots . \ldots \ldots .2$

4.2 RCRA Corrective Action Process $\ldots \ldots \ldots \ldots \ldots \ldots \ldots \ldots \ldots \ldots . \ldots \ldots$

\section{Tables}

3.1 Elmendorf AFB Remedial Investigation/Feasibility Study Program $\ldots \ldots \ldots \ldots .2$

3.2 Radium Chemical D\&D Project $\ldots \ldots \ldots \ldots \ldots \ldots \ldots \ldots \ldots \ldots \ldots \ldots . .3$

5.1 RCRA ER Process Schedules Through Closeout $\ldots \ldots \ldots \ldots \ldots \ldots \ldots . \ldots . \ldots$ 


\subsection{Introduction}

The purpose of this study was to assist the Pinellas Plant, Largo, Florida, in estimating workforce requirements for the anticipated environmental restoration (ER) mission. Pacific Northwest Laboratory (PNL)(a) has prepared workforce estimates required for ER and the decontamination and decommissioning (D\&D) at Pinellas Plant. These estimates are found in the following sections and were based on a comparison of several ER projects of similar magnitude, including Elmendorf Air Force Base (AFB), Hanford, and the Radium Chemical D\&D project in Queens, New York. The characterization of the Pinellas Plant was based on the RCRA [Resource Conservation and Recovery Act] Facility Investigation Report: Pinellas Plant.(b)

Section 2.0 discusses the assumptions that were made about the Pinellas Plant prior to proceeding with the workforce estimate. Using comparisons with projects at Elmendorf AFB and the Radium Chemical D\&D project, Section 3.0 provides information on the basis for the workforce estimation. Section 4.0 discusses the workforce/classification evaluation, and Section 5.0 describes the schedules for the RCRA ER process. References are found in Section 6.0.

(a) PNL is operated by Battelle Memorial Institute for the U.S. Department of Energy under Contract DE-AC06-76RLO 1830.

(b) RCRA Facility Investigation Report: Pinellas Plant. September 1991 (Draft). Draft Report, Los Alamos National Laboratory, Los Alamos, New Mexico. 


\subsection{Assumptions}

The following assumptions were made by PNL prior to beginning the Pinellas workforce estimate.

- The Pinellas Plant will continue with the RCRA process throughout ER. This may revert to the Comprehensive Environmental, Response Compensation, and Liability Act (CERCLA) process, but this should not - ffect the estimates.

- Sufficient data have been gathered through the RCRA Field Investigation.

- Additional field investigations will support corrective measure studies (CMSs) and designs.

- The workforce estimate will be based on CMS and Corrective Measure Implementation (CMI), as well as monitoring.

- The CMS will include treatability bench/pilot-scale studies.

- Most RCRA cleanup is assumed to be in-house with minimal subcontracting.

- The site will be managed as a single site, not as separate site cleanups.

- Subcontractors will be used for technical support to help onsite staff train, plan, develop, and implement ER and D\&D. 


\subsection{Basis for Estimation}

Various areas that helped to provide a basis for the workforce evaluation are outlined in the following.

1. Experience with the Elmendorf AFB CERCLA Program. PNL supported the Federal Facility Agreement Negotiation and Schedule for site cleanup.

2. PNL executed basewide, Operable Unit 4, and Operable Unit 5 remedial investigations. Pinellas Plant is comparable to one operable unit. An operable unit is a designated study area that may have individual sites for investigation and has common sources of contamination. Table 3.1 provides a list of the manhours and other services required for the program during a two-year period:

3. The D\&D scope is based upon experience for the Radium Chemical D\&D Project in Queens, New York. The Radium Chemical building was used to store radium needles for $x$-ray machines. A removal action was performed by the U. S. Environmental Protection Agency (EPA) Region 2 to extricate 120 curies of radium needles from the building. A D\&D was subsequently performed within a two-year schedule. Total manhours and profession categories were provided by the subcontractor performing the work; this was the basis for position categories and manhour estimates for this evaluation. The position categories and manhours presented in Table 3.2 reflect approximations for this projects.

Consideration needs to made about this project for use as a model for other D\&D work, as this project was an EPA Region 2 lead site. EPA Region 2 was interested in the progress of this project and in meeting a two-year schedule for completion. Therefore, this project was given special attention for streamlining regulatory aspects. Regulations were not circumvented, but there was a priority to get work done.

4. The Radium Chemical D\&D Project can be correlated to the Pinellas site. An assumption will be made that RCRA and CERCLA processes are very similar and take approximately the same length of time.

5. U.S. Department of Energy (DOE) sites usually take longer to clean up than U.S. Department of Defense (DoD) sites. DoD cleanups follow the CERCLA process. DOE follows CERCLA, National Environmental Policy Act, and DOE requirements, which increases the complexity and the time necessary to complete the work.

6. The Pinellas Plant estimate was based on the standard CERCLA process. This workforce baseline will be multiplied by a factor of 2.0 to account for the DOE process. This factor is based on experience with both DoD and DOE site cleanup cost estimates. For example, a standard work plan for investigation for a DoD site, on the average, will cost $\$ 200 \mathrm{~K}$. A work plan at a DOE site could cost between $\$ 350 \mathrm{~K}$ and $\$ 800 \mathrm{~K}$ because of the significant increase in review cycles to the final work plan. A draft work plan for the Corps of Engineers for Hanford 100FR-1 Site Investigation cost approximately $\$ 600 \mathrm{~K}$. This included the cost for finishing only the last five sections of the work plan. An average of $\$ 400 \mathrm{~K}$ had originally been assumed; therefore, a multiplier of 2.0 is used for this estimate. 
Table 3.1. Elmendorf AFB Remedial Investigation/Feasibility Study (RI/FS) Program(a)

Total Subcon-

\begin{tabular}{|c|c|c|}
\hline tractor Manhours (b) & Outside Services & Laboratory \\
\hline $49,100 \mathrm{hr}$ & $\begin{array}{l}\$ 335,000.00 \\
\text { (Approx. 3,500 hr) }\end{array}$ & $\begin{array}{l}\$ 369,000.00 \\
\text { (Approx. } 3,500 \mathrm{hr} \text { ) }\end{array}$ \\
\hline Descript & & umber \\
\hline $\begin{array}{l}\text { General Mar } \\
\text { Project Man } \\
\text { Engineer } \\
\text { Geologist } \\
\text { Technical Ec } \\
\text { Program Ad } \\
\text { Secretary } \\
\text { Word Proces } \\
\text { Draftsman } \\
\text { CAD Operat } \\
\text { Computer S } \\
\text { Administrat } \\
\text { Clerk }\end{array}$ & $\begin{array}{l}\text { ager } \\
\text { ger } \\
\text { tors } \\
\text { inistrator } \\
\text { sor } \\
\text { r } \\
\text { eialist } \\
\text { e Support }\end{array}$ & $\begin{array}{l}1 \\
2 \\
4 \\
5 \\
2 \\
2 \\
2 \\
2 \\
2 \\
1 \\
1 \\
2 \\
3\end{array}$ \\
\hline
\end{tabular}

(a) Assume same effort for remedial design is two years; assume same effort for remedial action is two years (total six-year program).

(b) Total manhours for CERCLA cleanup from start to finish is $56,100 \times 3=168,300 \mathrm{hr}$. 
Table 3.2. Radium Chemical D\&D Project

Description

Number

Onsite Personnel( $(\boldsymbol{)})$

Site Manager

Quality Assurance

Health and Safety

Site Engineer

Secretary

Support Lab(a)

Manager

Supervisor

Technician

Offsite Support(a)

Project Manager

Deputy Project Manager

Project Engineer

Staff Engineer

Geologist

Secretary

Technician

Accounts Receivable

Invoice Clerk

Corps of Engineers (COE) and EPA Staff(b)

EPA Project Manager

EPA Lawyer

EPA Administrative Support

EPA Secretary

COE PM

COE Contract Specialist

COE Technical Support

COE Secretary

(a) Assume a two-year schedule with totally burdened charge-out rate of $\$ 110 / \mathrm{hr}$. This includes per diem expenses for half of the personnel for two years ( 36 staff $\times 2,080$ working hr/ $\mathrm{yr}=149,760$ manhours; 149,760 manhours $\times \$ 110 / \mathrm{hr}=$ $\$ 16,473,600$ ).

(b) Assume these staff at one-quarter time for two years.

Therefore, 0.25 staff/full time employee (FTE) $x$

$2080 \mathrm{hr} \times 10 \mathrm{FTE}=5200 \mathrm{hr}$. Total manhours for

project $=149,760+5,200=154,960 \mathrm{hr}$, or $74.5 \mathrm{man}-\mathrm{yr}$. 


\subsection{Workforce/Classification Evaluation}

The following are occupation titles that may be needed for the overall RCRA environmental cleanup program at the Pinellas Plant (occupation titles are based on the Common Occupational Classification System (COCS) [Holmes et al. 1992]). The standard RCRA/CERCLA process is presented in Figures 4.1 and 4.2. An estimate was made for janitors, laundry workers, and security workers because these occupation classifications are not usually required on RCRAV CERCLA projects. To obtain the DOE estimate, multiply the quantity in each classification by two and double the amount of time.

\section{Description}

General Manager

First Line Supervisor

Program Manager

Project Manager

Chemical Engineer

Civil Engineer

Computer Engineer

Environmental Engineer

Mechanical Engineer

Electrical Engineer

Nuclear Engineer

Safety Engineer

Geologist

Social Scientist (Public Affairs Support)

Accountant and Auditor

Computer Systems Analyst

Cost Estimator/Planner/Scheduler

Health Physicist

Industrial Hygienist

Lawyer

Personnel and Labor Relations Specialist

Technical Writers and Editor

Administrative Assistant

Office Clerk

Office Clerk Specialized

Secretary

Typist/Word Processor

Technician

Drafter

Health Physics Technician

Industrial Safety Technician

Instrument and Control Technician

Laboratory Technician

Driller

Laborer

Janitor

Laundry Worker

Security

Total Work Force (not including subcontractors)
Number

1

1

2

4.1 


\section{CORRECTIVE ACTION PROCESS}

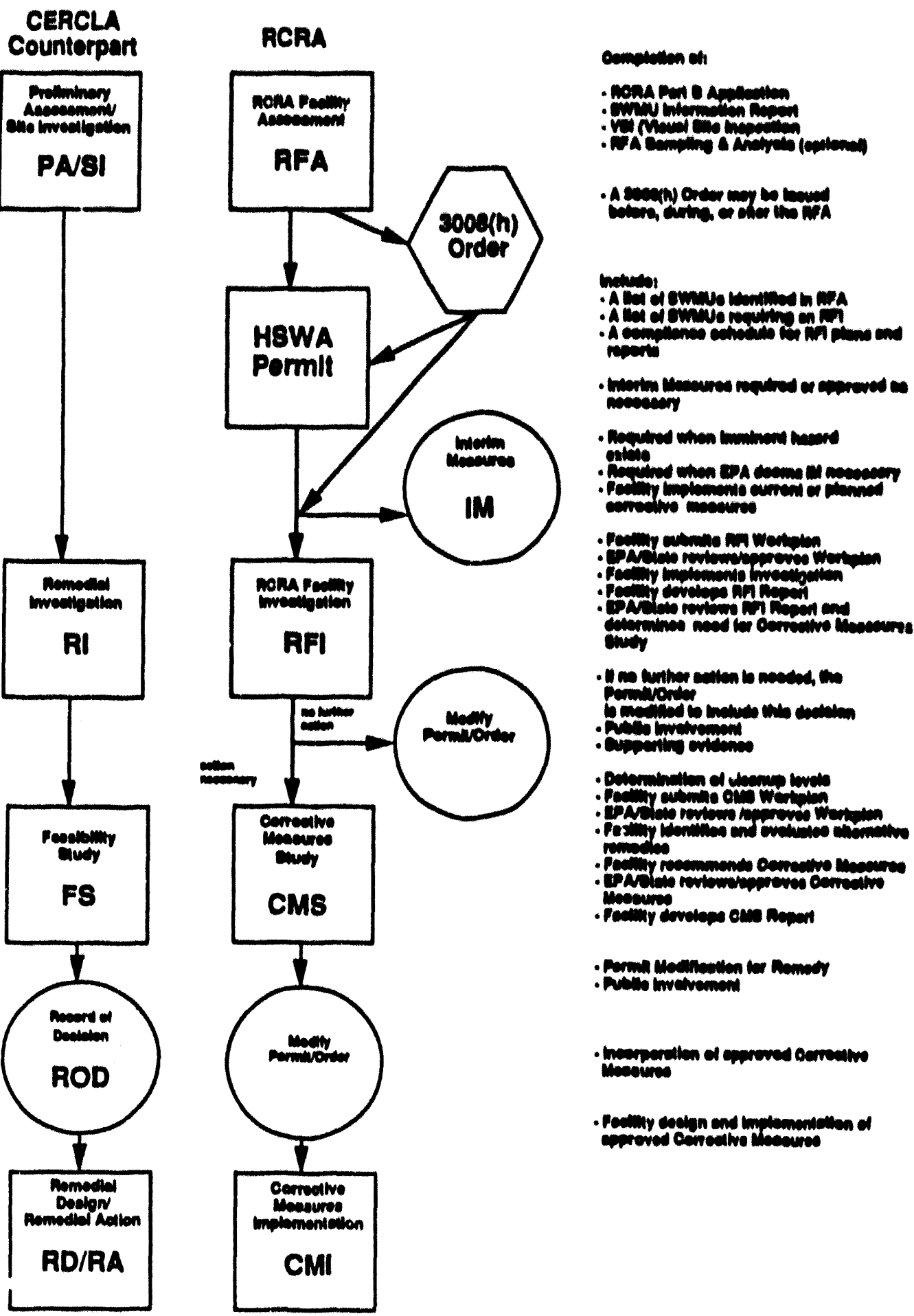

Figure 4.1. Corrective Action Process (adapted from EPA 540 G-89 004 [EPA June 1988]) 


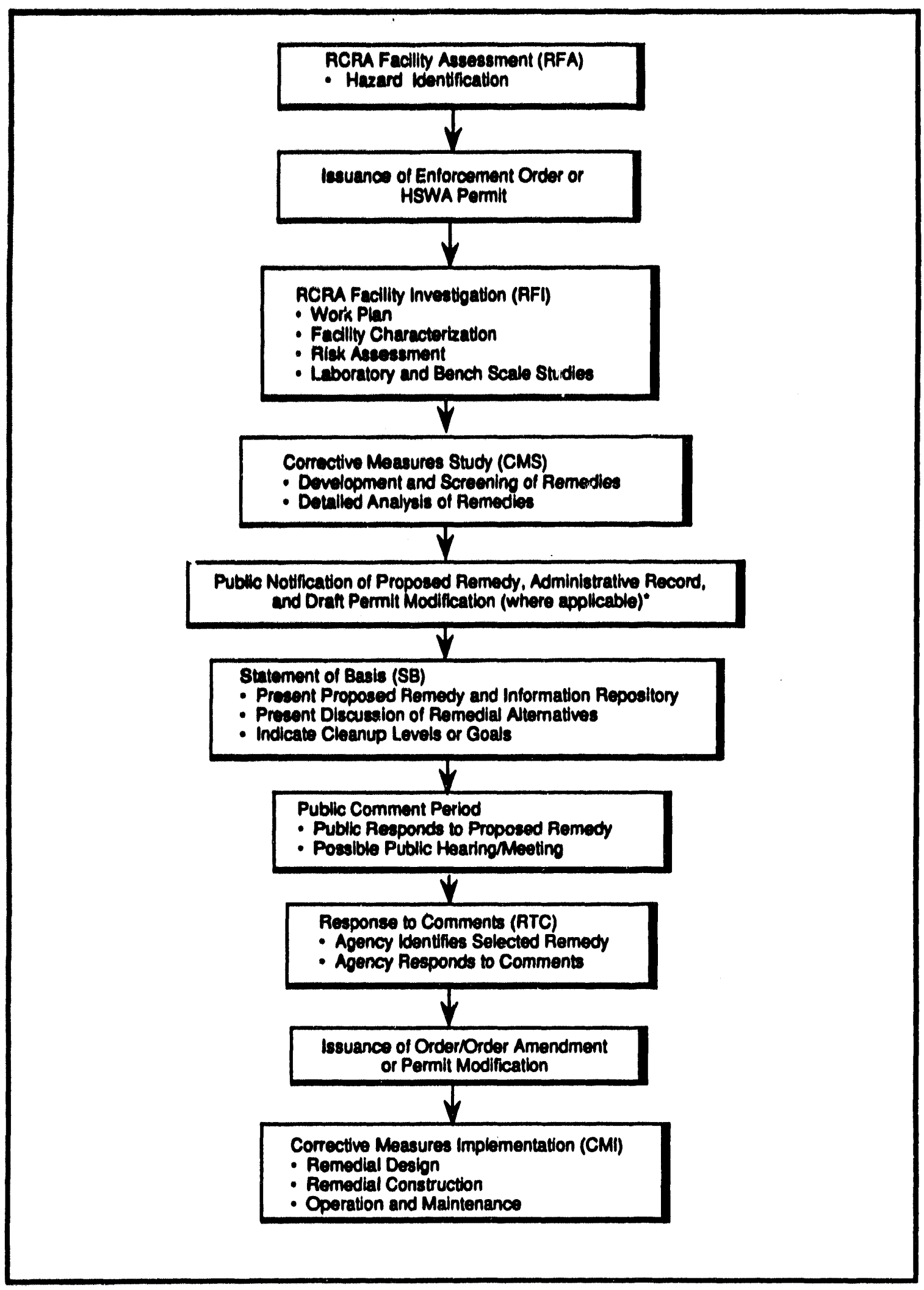

- The edministrative record ahould be accealble to the publle during the entive corrective action procese

Figure 4.2. RCRA Corrective Action Process (adapted from EPA 530-SW-88-028 [EPA October 1988]) 


\subsection{Schedules for RCRA Environmental Restoration Process from CMS to Site Closeout}

The following table provides the schedules for the RCRA ER process.

Table 5.1. RCRA ER Process Schedules Through Closeout

Item

Corrective Measure Study

Planning

Planning Review and Approval

Work Plan Development(a)

Work Plan Review

Work Plan Finalization

Investigation Mobilization

Field Work

Laboratory Analysis

Data Validation

Laboratory Report

Bench/Pilot Scale Testing and Evaluation

(includes set up, laboratory analysis, and

report preparation)

Evaluation of Data and Remedy Selection

CMS Report Preparation

CMS Review and Approval

Subtotal

Public Relations Program

Develop Public Relations Plan

Public Relations Plan Review and Approval

Implement and Maintain Public Relations Program
Time Erame (Conservative)

6 Weeks

8 Weeks

12 Weeks

6 Weeks

6 Weeks

4 Weeks

8 Weeks

16 Weeks

8 Weeks

8 Weeks

52 Weeks

6 Weeks

12 Weeks

12 Weeks

164 Weeks

16 Weeks

16 Weeks

Throughout program

(a) Work plan will develop and design investigations and bench-/pilot-scale studies that will lead to selection of remedies for environmental restoration. This will involve investigations to gather data to design bench/pilot scale studies and an evaluation of data to recommend selected remedies.

Remedial designs normally take 72 weeks after the Record of Decision or RCRA permit approval and 32 weeks to procure a remedial action contractor. Remedial action should take 144 weeks on large-scale remedial actions, totaling 412 weeks (8 years) for ER, from the start to completion. 


\subsection{References}

Holmes, C. W., R. E. Lewis, S. T. Hunt, and M. G. Finn. 1992. Environmental Restoration and Waste Management: U.S. Department of Energy Complex, PNL-8171, Addendum 1, Pacific Northwest Laboratory, Richland, Washington.

U.S. Environmental Protection Agency (EPA). June 1988. RCRA Corrective Action Plan (Interim Final). EPA 530-SW-88-028, OSWER Directive 9902.3.

U.S. Environmental Protection Agency (EPA). October 1988. Guidance for Conducting Remedial Investigations and Feasibility Studies Under CERCLA (Interim Final). EPA 540 G-89 004, OSWER Directive 9655 2-01. 


\section{Distribution}

No. of

Copies

OFESITE

12 DOE/Office of Scientific and Technical Information
No. of

Copies

ONSITE

DOE Richland Operations Office

D. J. Sansotta

13 Pacific Northwest Laboratory

J. G. April

R. L. Lewis

E. J. Stahlman (5)

Publishing Coordination

Technical Report Files (5) 

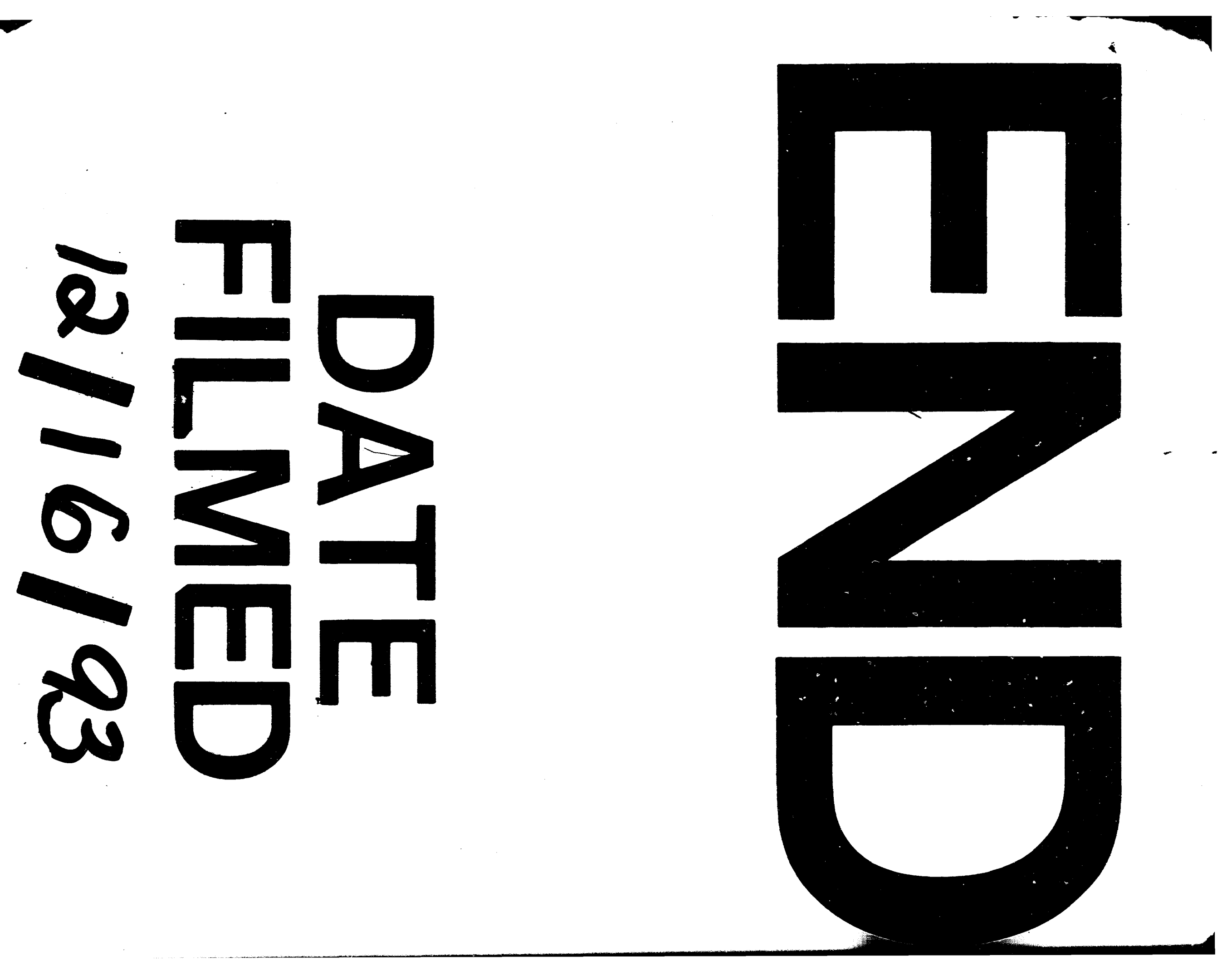
$$
\text { - }
$$$$
-
$$ 